\title{
Knowledge Management Capability in Nepalese Commercial Banks
}

\begin{abstract}
Dilliram Bhandari*
Abstract

This study focuses on exploring the state of knowledge management capability (KMC) in Nepalese commercial banks and develop as well as validate its dimensions. A survey research strategy was adopted to achieve the study objective and the descriptive research design was followed to explore the state of KMC in Nepalese commercial banks. The population of this study was comprised of all 27 commercial banks of Nepal. To achieve sufficient sample size and generalization of the result, the sample frame for this study included 9 commercial banks. At least 20 employees from each organization were approached to respond about the existence of KMC in their respective organizations. Altogether 250 questionnaires were distributed, out of this 180 questionnaires were returned, the response rate was $72 \%$, which may be taken highly satisfactory in survey research design. The exploratory factor analysis (EFA) of KMC was done to extract the latent factors or dimensions from the measured items. All three dimensions of KMC were found in unsatisfactory state. The private sector banks were found to have a better position in all three dimensions of KMC than the public sector banks. Further, the EFA of KMC items revealed for dimensions of KMC: knowledge acquisition, knowledge sharing-employees, knowledge sharing-management and knowledge utilization.
\end{abstract}

Key Words: knowledge acquisition, knowledge sharing-employees, knowledge sharingmanagement and knowledge utilization.

\section{Introduction}

Background

Knowledge workers have become the most vital asset in the knowledge-based society (Drucker,1993). Knowledge management (KM) is aimed at getting people to innovate, collaborate, and make correct decisions efficiently; in short, it is aimed at getting people to act by focusing on high-quality knowledge (June, 2005). Jantunen (2005) states that knowledge is posited in an organization as a strategic asset which can help the firm maintain its competitive ability in a turbulent environment. Knowledge is considered the most important resource in organizations (Choe, 2004), and the characteristics and problems of knowledge do not differ because of different geographic locations (Singh et al., 2008). Hence, a knowledgeable administrative manager should know how to effectively distribute or allocate knowledge

${ }^{*}$ Dr. Bhandari is Lecturer, Shanker Dev Campus, Kathmandu, TU, Nepal 
to maximize utility. A successful corporate KM comes from the support of high-level management and the fundamental investment in HRM.

With relatively small market size, the banking sector is facing competition for innovative financial-services. They may not be able to withstand competition with the traditional sources such as capital and technology. They must improve and innovate continuously to grow and sustain by leveraging their human resource through a continuous learning and build knowledge assets for a sustainability and success.

In conjunction with the above issues, this study focuses to Nepalese banking industry. By now, this industry has turned to be very competitive primarily due to liberalization of Nepalese economy. Under such situation, knowledge development and management for innovation becomes a key factor for the banking industry to withstand competition and achieve sustainability.

\section{Statement of the Problem and Research Questions}

Knowledge management $(\mathrm{KM})$ is based on the premise that, just as human beings are unable to draw on the full potential of their brains, organizations are generally not able to fully utilize the knowledge that they possess. Through KM, organizations seek to acquire or create potentially useful knowledge and to make it available to those who can use it at a time and place that is appropriate for them to achieve maximum effective usage in order to positively influence organizational performance (King, 2008). It is generally believed that if an organization can increase its effective knowledge utilization by only a small percentage, great benefits will result.

Nepalese organizations are operating in a complex and dynamic environment. They have started realizing that they cannot withstand the complexity through the traditional resources such as capital and technology as a result of which they now should focus on learning and knowledge for competitive advantage and sustainability. In relation to the above issues, this study attempts to address the following questions.

1. What is the state of KMC in the Nepalese commercial banks?

2. What is the valid KMC model of Nepalese commercial banks?

\section{Research Objectives}

This study primarily focuses on exploring the state of KMC in Nepalese commercial banks and develop as well as validate the dimensions of KMC. Hence, this study attempts to achieve the following objectives.

1. To explore the state of KMC as perceived by the employees in the Nepalese commercial banks.

2. To develop and validate the KMC model of Nepalese commercial banks? 


\section{Significance of the Study}

This study attempts to explore the KMC of Nepalese commercial banks. It further attempts to develop and validate the dimension of KMC. This study is worthy in the pretext that KM in Nepalese organizations is a new and understudied area. Nepalese organizations still do not take knowledge as a source of competitive advantage. This study is expected to provide an insight of the dimensions through which KMC can be enhanced.

\section{Literature Review \\ Knowledge Management Capability}

In recent years, the term knowledge management has been debated, defined, and redefined repeatedly. It is defined as the tools, techniques, and strategies to retain, analyze, organize, improve, and share business expertise.

Managerial capability can refer to a firm's skills, knowledge, and experiences, which are used to handle difficult and complex tasks in management and production (Choi and Shepherd, 2004). Knowledge is considered the most important resource in organizations (Choe, 2004), and the characteristics and problems of knowledge do not differ because of different geographic locations (Singh et al., 2008). Knowledge is posited in an organization as a strategic asset which can help a firm maintain its competitiveness in a turbulent environment (Jantunen, 2005). Knowledge-based assets and OL capabilities are critical for a firm's innovation activities (Jantunen, 2005).

$\mathrm{KM}$ is a business process wherein firms create and use their institutional or collective knowledge (Sarvary, 1999). KM includes three sub-processes: OL, knowledge production, and knowledge distribution - the process that allows members of the organization to access and use the collective knowledge of the firm. There are four steps to integrate KM into the organization's quality strategy: capturing or creating knowledge (plan), sharing knowledge (do), measuring the effects (check) and learning and improving (act) (Lim et al., 1999). KM is aimed at getting people to innovate, to collaborate, and to make correct decisions efficiently; in short, it is aimed at getting people to act by focusing on high-quality knowledge (Du Plessis, 2005). Knowledge management capacity has been recognized as a key factor for gaining and sustaining a competitive advantage (Corsoa et al., 2006; Rezgui, 2007).

Nepalese studies related to knowledge management are rare. Chalise (2011) studied the knowledge management practices of Nepalese public and private sector banks. The main objective of this study was to examine the contribution of knowledge management to banking performance. Heconcluded that if the commercial banks of Nepal plan to implement knowledge management, they should grabble with business strategy, technology, organizational culture and human resources in order to have an effective knowledge management that could sustain their competitive advantage. He found a positive relationship between the factors of knowledge management practice of Nepalese commercial banks. 
Shrestha (2008) concluded that there is still need of improve to knowledge acquisition or implementation or implementation activities in Nepalese banking industry.

\section{Knowledge Management Capability Measures}

Existing literature presents various measurements of KMC in organizations. For example, Marquardt (1996) identifies KMC consisting four components: knowledge acquisition, knowledge creation, knowledge storage, as well as knowledge transfer and application. Hsu et al. (2007) identify four factors which affect the adoption of KM: information technology, complexity of management and marketing, formal documentation status as well as knowledge acquisition mechanisms. Similarly, Zack (1999) demonstrates four elements of KMC, namely knowledge acquisition, refinement, storage and retrieval, as well as presentation. Gold et al. (2001) conclude that organizations' should possess two basic abilities to manage knowledge, namely knowledge infrastructure capability and knowledge process capability. Furthermore, Tiwana (2002) proposes that organizational KMCs include finding, creating new, packaging, assembling, reusing and revalidating knowledge. Alavi and Leidner (2001) point out the abilities to create, store, retrieve, transfer and apply knowledge are considered the core of implementing KM in organizations. Moreover, Gottschalk (2006) identifies five indicators of $\mathrm{KMC}$, including knowledge sharing, knowledge distributing, knowledge creating, knowledge capturing and understanding knowledge. Cepeda and Vera (2007) suggest four categories of $\mathrm{KMC}$, namely knowledge creation, knowledge transfer, knowledge retention, and knowledge utilization. Thus, according to the above research, KMC can be classified into three factors, including learning and obtaining, sharing knowledge, and creating and improving knowledge.

From a cross-unit perspective, Tanriverdi (2005) proposes a multi-business firm concept, which divides KMC into two categories: KM within and KM across business units. However, every KMC must go through a four-step process, including creation of related knowledge, transfer of related knowledge, integration of related knowledge and leverage of related knowledge.

In considerations to the above literatures, $\mathrm{KMC}$ was measured through three dimensions.

Table: 1

Measures of Knowledge Management Capability

\begin{tabular}{lll}
\hline \multicolumn{1}{c}{ Construct } & \multicolumn{1}{c}{ Description of measurement } & \multicolumn{1}{c}{ References } \\
\hline $\begin{array}{l}\text { 1. Knowledge } \\
\text { acquisition }\end{array}$ & $\begin{array}{l}\text { Four items were used to measure } \\
\text { knowledge acquisition by the } \\
\text { organization }\end{array}$ & $\begin{array}{l}\text { Leary (1998); Chang Lee et al. } \\
\text { (2005); Shih and Chiang (2005) }\end{array}$ \\
$\begin{array}{l}\text { 2. Knowledge } \\
\text { sharing }\end{array}$ & $\begin{array}{l}\text { Six items were used to measure } \\
\text { the extent to which diffusion of } \\
\text { knowledge is promoted }\end{array}$ & $\begin{array}{l}\text { Sviokla (1996); Ruggles (1998); } \\
\text { Chang Lee et al.(2005); Shih and } \\
\text { Chiang (2005) }\end{array}$
\end{tabular}


3. Knowledge Five items were used to measure utilization the degree to which employees retrieve information, process and apply it
Wiseman (1988); Weber et al. (1990); Blanning and David (1995); Chang Lee et al. (2005)

\section{Methodology}

A survey research strategy was adopted to achieve the study objective and the descriptive research design was followed to explore the state of KMC in Nepalese commercial banks.

The population of this study was comprised of all 27 commercial banks of Nepal. To achieve sufficient sample size and generalization of the result, the sample frame for this study included 9 commercial banks. The informants of this study were the middle and top-level employees of the sample banks from both branch and corporate (head) office who were expected to have better knowledge and understandings of the existence of KMC in their respective organizations better than other employees.

At least 20 employees from each organization were approached to respond about the existence of OLC in their respective organizations. Altogether 250 questionnaires were distributed, out of this 180 questionnaires were returned, the response rate was $72 \%$, which may be taken highly satisfactory in survey research design. EFA of KMC was done to extract the latent factors or dimensions from the measured items.

\section{Analysis and Presentation}

The data analysis section of this study has been divided into two parts. The first part includes the descriptive analysis of KMC. The second part of this section of data analysis includes the development of dimensions of KMC by applying exploratory factor analysis.

\section{Descriptive Analysis of Knowledge Management Capability}

Knowledge management capability (KMC) was measured as three dimensional construct namely knowledge acquisition, knowledge sharing and knowledge utilization. KMC was measured using a seven point likert scale ranging 1 strongly unsatisfactory to 7 strongly satisfactory. The result of descriptive statistics related to KMC is presented below.

\section{Descriptive analysis of knowledge acquisition}

Knowledge acquisition is the first dimension of KMC used in this study. Four items were used to measure this dimension. The result from descriptive statistics related to knowledge acquisition has been presented below: 
Table:

Descriptive Statistics of Knowledge Acquisition

\begin{tabular}{|c|c|c|c|c|c|c|c|}
\hline \multicolumn{3}{|l|}{ Items } & $\mathbf{N}$ & Mean & $\begin{array}{c}\text { Std. } \\
\text { Deviation }\end{array}$ & F & Significance \\
\hline \multicolumn{3}{|l|}{ Knowledge Acquisition } & 252 & 3.3948 & 0.73667 & 19.070 & 0.000 \\
\hline \multirow{3}{*}{$\begin{array}{l}\text { Interaction directly with customers } \\
\text { to learn how to serve them better. }\end{array}$} & \multirow{3}{*}{ 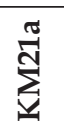 } & Public & 69 & 3.17 & 0.954 & 13.294 & 0.000 \\
\hline & & Private & 183 & 3.63 & 0.854 & & \\
\hline & & Total & 252 & 3.50 & 0.904 & & \\
\hline \multirow{3}{*}{$\begin{array}{l}\text { Market research to know the needs } \\
\text { and preferences of the customers } \\
\text { and changes if any. }\end{array}$} & \multirow{3}{*}{$\sum_{i}^{O}$} & Public & 69 & 3.06 & 0.938 & 18.099 & 0.000 \\
\hline & & Private & 183 & 3.59 & 0.865 & & \\
\hline & & Total & 252 & 3.44 & 0.915 & & \\
\hline \multirow{3}{*}{$\begin{array}{l}\text { Collection of information regarding } \\
\text { the competitors regularly. }\end{array}$} & \multirow{3}{*}{$\sum_{i}^{\mathscr{E}}$} & Public & 69 & 3.00 & 0.874 & 14.162 & 0.000 \\
\hline & & Private & 183 & 3.42 & 0.758 & & \\
\hline & & Total & 252 & 3.31 & 0.812 & & \\
\hline \multirow{3}{*}{$\begin{array}{l}\text { Search through customer and } \\
\text { task-related databases to obtain } \\
\text { knowledge necessary for the tasks. }\end{array}$} & \multirow{3}{*}{$\sum_{\underline{1}}^{\vec{D}}$} & Public & 69 & 3.07 & 0.944 & 8.478 & 0.004 \\
\hline & & Private & 183 & 3.42 & 0.807 & & \\
\hline & & Total & 252 & 3.33 & 0.859 & & \\
\hline \multirow{3}{*}{\multicolumn{2}{|c|}{ Total }} & Public & 69 & 3.0761 & 0.82505 & & \\
\hline & & Private & 183 & 3.5150 & 0.66412 & & \\
\hline & & Total & 252 & 3.3948 & 0.73667 & & \\
\hline
\end{tabular}

The descriptive statistics of knowledge acquisition reveals that Nepalese commercial banks are facing a week state of knowledge acquisition in their organizations (Mean 3.394 SD 0.737). Both types of commercial banks are found to have a week state of knowledge acquisition (Public: Mean 3.076 SD 0.825, Private: Mean 3.515 SD 0.664). Significant differences exist between the public and private banks in knowledge acquisition (F-19.07 P- 0.00).

\section{Descriptive Analysis of Knowledge Sharing}

The second dimension of KMC used in this study is knowledge sharing. Six different items are used to measure the extent to which diffusion of knowledge is promoted within as well as outside the organization. The result of descriptive statistics related to knowledge sharing is presented below: 
Table:

Descriptive Statistics of Knowledge Sharing

\begin{tabular}{|c|c|c|c|c|c|c|c|}
\hline \multicolumn{3}{|l|}{ Items } & $\mathbf{N}$ & Mean & $\begin{array}{c}\text { Std. } \\
\text { Deviation }\end{array}$ & F & Significance \\
\hline \multicolumn{3}{|l|}{ Knowledge Sharing } & 252 & 3.6878 & 0.72182 & 10.783 & 0.001 \\
\hline \multirow{3}{*}{$\begin{array}{l}\text { Employee's willingness of } \\
\text { knowledge sharing }\end{array}$} & \multirow{3}{*}{ 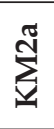 } & Public & 69 & 3.13 & 1.028 & 12.841 & 0.000 \\
\hline & & Private & 183 & 3.66 & 1.056 & & \\
\hline & & Total & 252 & 3.52 & 1.073 & & \\
\hline \multirow{3}{*}{$\begin{array}{l}\text { Encouragement of management for } \\
\text { informal discussion }\end{array}$} & \multirow{3}{*}{$\sum_{i}^{\stackrel{0}{\Sigma}}$} & Public & 69 & 3.48 & .949 & 0.198 & 0.656 \\
\hline & & Private & 183 & 3.55 & 1.243 & & \\
\hline & & Total & 252 & 3.53 & 1.169 & & \\
\hline \multirow{3}{*}{$\begin{array}{l}\text { Encouragement of community of } \\
\text { practice }\end{array}$} & \multirow{3}{*}{$\sum_{\underline{\Sigma}}^{\tilde{N}}$} & Public & 69 & 3.04 & 0.930 & 5.468 & 0.020 \\
\hline & & Private & 183 & 3.43 & 1.233 & & \\
\hline & & Total & 252 & 3.32 & 1.169 & & \\
\hline \multirow{3}{*}{$\begin{array}{l}\text { Encouragement by management to } \\
\text { share knowledge }\end{array}$} & \multirow{3}{*}{ 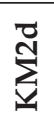 } & Public & 69 & 3.46 & .917 & 0.252 & 0.616 \\
\hline & & Private & 183 & 3.54 & 1.147 & & \\
\hline & & Total & 252 & 3.52 & 1.088 & & \\
\hline \multirow{3}{*}{$\begin{array}{l}\text { Knowledge shariang as a base of } \\
\text { performance appraisal }\end{array}$} & \multirow{3}{*}{ 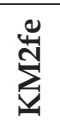 } & Public & 69 & 3.71 & 0.956 & 8.432 & 0.004 \\
\hline & & Private & 183 & 4.16 & 1.140 & & \\
\hline & & Total & 252 & 4.04 & 1.109 & & \\
\hline \multirow{3}{*}{$\begin{array}{l}\text { Use of information system for } \\
\text { knowledge sharing }\end{array}$} & \multirow{3}{*}{ 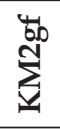 } & Public & 69 & 3.87 & 1.083 & 7.186 & 0.008 \\
\hline & & \begin{tabular}{|l|} 
Private \\
\end{tabular} & 183 & 4.33 & 1.254 & & \\
\hline & & Total & 252 & 4.20 & 1.225 & & \\
\hline \multirow{3}{*}{\multicolumn{2}{|c|}{ Total }} & Public & 69 & 3.4493 & 0.59292 & & \\
\hline & & Private & 183 & 3.7778 & 0.74665 & & \\
\hline & & Total & 252 & 3.6878 & 0.72182 & & \\
\hline
\end{tabular}

The descriptive statistics of knowledge sharing reveal that Nepalese commercial banks are facing a week state of knowledge sharing in their organizations (Mean 3.688 SD 0.722). Both types of commercial banks are found to have a weak state of knowledge sharing (Public: Mean-3.449, SD- 0.593 Private: Mean- 3.778 SD- 0.747). Significant differences exist between the public and private banks in knowledge acquisition (F- 10.83 P- 0.001).

\section{Descriptive Statistics of Knowledge Utilization}

The third and last dimension of KMC used in this study is knowledge utilization. Five different items were used to measure the degree to which employees retrieve information, process and apply it. The result of descriptive statistics of knowledge utilization has been presented below: 
Table: 4

Descriptive Statistics of Knowledge Utilization

\begin{tabular}{|c|c|c|c|c|c|c|c|}
\hline \multicolumn{3}{|l|}{ Items } & $\mathbf{N}$ & Mean & $\begin{array}{c}\text { Std. } \\
\text { Deviation }\end{array}$ & F & Significance \\
\hline \multicolumn{3}{|l|}{ Knowledge Utilization } & 252 & 3.3349 & 0.69938 & 6.741 & 0.010 \\
\hline \multirow{3}{*}{$\begin{array}{l}\text { Existence of research and educational } \\
\text { program }\end{array}$} & \multirow{3}{*}{$\sum^{\infty}$} & Public & 69 & 3.35 & 0.819 & .227 & 0.634 \\
\hline & & Private & 183 & 3.29 & 0.882 & & \\
\hline & & Total & 252 & 3.31 & 0.864 & & \\
\hline \multirow{3}{*}{$\begin{array}{l}\text { Promotion of teamwork by utilizing } \\
\text { organizational knowledge }\end{array}$} & \multirow{3}{*}{$\sum_{\underline{\Sigma}}^{\hat{m}}$} & Public & 69 & 3.32 & 0.813 & 1.470 & 0.226 \\
\hline & & Private & 183 & 3.47 & 0.907 & & \\
\hline & & \begin{tabular}{|l|} 
Total \\
\end{tabular} & 252 & 3.43 & 0.883 & & \\
\hline \multirow[t]{3}{*}{ Use of electronic data to process task } & \multirow{3}{*}{$\sum_{\Sigma}^{\mathscr{g}}$} & Public & 69 & 3.36 & 0.804 & 7.693 & 0.006 \\
\hline & & Private & 183 & 3.73 & 0.973 & & \\
\hline & & Total & 252 & 3.63 & 0.942 & & \\
\hline \multirow{3}{*}{$\begin{array}{l}\text { Incentive and benefit policies for new } \\
\text { idea suggestions }\end{array}$} & \multirow{3}{*}{$\sum_{\underline{\Sigma}}^{\mathbb{m}}$} & Public & 69 & 2.91 & 0.887 & 2.477 & 0.117 \\
\hline & & Private & 183 & 3.10 & 0.813 & & \\
\hline & & \begin{tabular}{|l|} 
Total \\
\end{tabular} & 252 & 3.05 & 0.836 & & \\
\hline \multirow{3}{*}{$\begin{array}{l}\text { Existence of culture of knowledge } \\
\text { sharing }\end{array}$} & \multirow{3}{*}{$\sum_{\Sigma}^{\infty}$} & Public & 69 & 2.81 & 0.879 & 22.325 & 0.000 \\
\hline & & Private & 183 & 3.44 & 0.958 & & \\
\hline & & Total & 252 & 3.27 & 0.976 & & \\
\hline \multirow{3}{*}{\multicolumn{2}{|c|}{ Total }} & Public & 69 & 3.1507 & 0.72307 & 6.741 & 0.010 \\
\hline & & Private & 183 & 3.4044 & 0.67935 & & \\
\hline & & Total & 252 & 3.3349 & 0.69938 & & \\
\hline
\end{tabular}

The descriptive statistics of knowledge utilization reveal that Nepalese commercial banks have a week state of knowledge utilization in their organizations (Mean 3.335 SD 0.699). Both types of commercial banks are found to have a weak state of knowledge acquisition (Public: Mean-3.151, SD- 0.723 Private: Mean-3.404, SD- 0.679). A significant difference exists between the public and private banks in knowledge acquisition (F- 6.741, P- 0.010).

\section{Exploratory Factor Analysis of Knowledge Management Capability}

EFA was used to identify the underlying dimensions of KMC in Nepalese commercial banks from the employees' perspective. The 15 items in the questionnaire were analyzed using principal component analysis with varimax rotation.

The theoretical concepts of KMC were taken from previous studies that provide theoretical justification for the present study. Some of the items were modified to match the KMC of Nepalese commercial banks. The result of the exploratory factor analysis of KMC has been presented in the following table. 
Table: 5

Exploratory Factor Analysis of Knowledge Management Capability

\begin{tabular}{|c|c|c|c|c|c|}
\hline & $\begin{array}{c}\text { Knowledge } \\
\text { Utilization }\end{array}$ & $\begin{array}{l}\text { Knowledge } \\
\text { Acquisition }\end{array}$ & $\begin{array}{c}\text { Knowledge } \\
\text { Sharing- } \\
\text { Employee }\end{array}$ & $\begin{array}{l}\text { Knowledge } \\
\text { Sharing- } \\
\text { Management }\end{array}$ & Communalities \\
\hline Cronbach's a & 0.834 & 0.865 & 0.835 & 0.741 & \\
\hline Eigen value & 4.426 & 2.521 & 1.884 & 1.484 & \\
\hline $\begin{array}{l}\% \text { of variance } \\
\text { explained } \\
\text { (Total } 68.767 \text { ) }\end{array}$ & 29.504 & 16.808 & 12.561 & 9.894 & \\
\hline KM1a & & 0.798 & & & 0.711 \\
\hline KM1b & & 0.827 & & & 0.744 \\
\hline KM1c & & 0.826 & & & 0.713 \\
\hline KM1d & & 0.822 & & & 0.705 \\
\hline KM2a & & & & 0.784 & 0.647 \\
\hline KM2b & & & & 0.805 & 0.651 \\
\hline KM2c & & & & 0.823 & 0.691 \\
\hline KM2d & & & 0.847 & & 0.733 \\
\hline KM2e & & & 0.885 & & 0.814 \\
\hline KM2f & & & 0.846 & & 0.717 \\
\hline KM3a & 0.790 & & & & 0.716 \\
\hline KM3b & 0.753 & & & & 0.656 \\
\hline KM3c & 0.778 & & & & 0.670 \\
\hline KM3d & 0.769 & & & & 0.638 \\
\hline KMЗе & 0.673 & & & & 0.508 \\
\hline \multicolumn{5}{|c|}{ Kaiser-Meyer-Olkin Measure of Sampling Adequacy. } & 0.765 \\
\hline \multirow{3}{*}{\multicolumn{2}{|c|}{ Bartlett's Test of }} & \multicolumn{3}{|c|}{ Approx. Chi-Square } & 1652.381 \\
\hline & & \multicolumn{3}{|l|}{$\mathrm{df}$} & 105 \\
\hline & & \multicolumn{3}{|l|}{ Sig. } & 0.000 \\
\hline
\end{tabular}

The Bartlett's Test of Sphericity $(\mathrm{p}<0.001)$ as shown by the above table shows that the factor model of KMC was highly appropriate (Norusis, 1994). The Kaiser-Meyer-Olkin measure of sampling adequacy (0.765) is above the cut point of 0.6. It shows that the samples are adequate for factor model.

The convergent validity or quality of the items that composed each factor was also analyzed based on Pasquali's (2008). Out of the 15 items of KMC, only 1 item KM4e has factor loadings from 0.6 to 0.7 . Hence, the factors satisfy the convergent validity.

The correlations between factors of KMC were not above 0.70 . Hence, the factors satisfy discriminant validity (Gaskin and Lim, 2016).

The factor structure representing KMC practices are meaningful, useful and conceptually sound. Hence, they satisfy face validity. 
The KMC measures were found to be highly reliable. All the factors of KMC showed high reliability, with a coefficients higher than 0.741. Following the recommended threshold recommended by authors such as Nunnally and Bernstein (1994), and Peterson (1994), the factor model can be regarded as reliable.

\section{Discussion and Implication}

All three dimensions of KMC were found in unsatisfactory state. The private sector banks were found to have a better position in all three dimensions of KMC than the public sector banks. The analysis of KMC further showed significant difference between public and private banks in all three dimensions of KMC namely knowledge acquisition, knowledge sharing and knowledge utilization.

Four different factors were identified from 15 observed items of KMC. They were knowledge acquisition, knowledge sharing-employee, knowledge sharing-organization and knowledge utilization. The KMO measure of 68.77 showed that the factor model was highly appropriate. The total variance explained by these factors was 68.77 percent which is higher than threshold level of 60 percent. All the factors had a coefficients higher than 0.741 . All the factor loadings were higher than 0.673 . Hence, the four factor model of KMC is regarded as valid as well as reliable for further analysis.

This study has made an important contribution in understanding KMC in Nepalese banking sector. It is particularly important in Nepalese context where organizations are reluctant in investing in innovative KM practices as they are still not convinced that KMC matters for performance improvement.

\section{Limitations and Directions for Future Research}

This study has a number of limitations. First, given the use of cross-sectional data, causality cannot be inferred. It may take a longer time to materialize the KMC. Future research may employ a longitudinal research design that examines the KMC to capture the time lag effects necessary to realize the benefits of the KMC. Another limitation of this study would be the use of subjective measures of KMC.

\section{References}

Adhikari D.R. (2005). Human Resource Management. Kathmandu: Buddha Academic Enterprises Pvt Ltd.

Alavi, M. and Leidner, D. (2001). Review: knowledge management and knowledge management systems: conceptual foundations and research issues. MIS Quarterly, 25(1), 107-136.

Blanning, R.W. and David, K. (1995). Organizations Intelligence. Washington, DC: Computer Society Press. 
Cepeda, G. and Vera, D. (2007). Dynamic capabilities and operational capabilities: a knowledge management perspective. Journal of Business Research, 60(5), 426-37.

Chalise (2011). Knowledge management: an evidence from Nepalese commercial banks (Unpublished Phd thesis). Department of Management, Tribhuwan University, Kathmandu, Nepal.

Chang Lee, K., Lee, S. and Kang, I.W. (2005). KMPI: measuring knowledge management performance. Information and Management, 42(3), 469-82.

Choi, Y.R. and Shepherd, D.A. (2004). Entrepreneurs' decisions to exploit opportunities. Journal of Management, 30(3), 377-95.

Corsoa, M., Martinib, A., Pellegrinib, L., Massac, S. and Testac, S. (2006). Managing dispersed workers: the new challenge in knowledge management. Technovation, 26(5/6), 58394.

Davenport, T. and Prusak, L. (1998). Working Knowledge: How Organizations Manage What They Know. Boston : Harvard Business School Press,MA.

Dawson, R. (2000). Knowledge capabilities as the focus of organizational development and strategy. Journal of Knowledge Management, 4(4), 320-27.

Drucker, P. (1993). Post Capitalist Society. Oxford: Butterworth-Heinemann.

Du Plessis, M. (2005). Drivers of knowledge management in the corporate environment. International Journal of Information Management, 25(3), 193-202.

Gaskin, J. \& Lim, J. (2016). Model Fit Measures. AMOS Plugin. .

Gold, A.H., Malhotra, A. and Segars, A.H. (2001). Knowledge management: an organizational capabilities perspective. Journal of Management Information Systems, 18(1), 185-214.

Gottschalk, P. (2006). Research propositions for knowledge management systems supporting electronic business. International Journal of Innovation and Learning, 3(6), 593-606.

Hsu, R-C., Lawson, D. and Lang, T-P. (2007). Factors affecting knowledge management adoption of Taiwan small and medium-sized enterprises. International Journal of Management and Enterprise Development, 4(1), 30-51

Huselid, M.A. (1995). The impact of human resource management practices on turnover, productivity, and corporate financial performance. Academy of Management Journal, 38(3), 635-72.

Jantunen, A. (2005). Knowledge-processing capabilities and innovative performance: an empirical study. European Journal of Innovation Management, 8(3), 336-49.

King, W.R. (2008). An integrated architecture for the effective knowledge organization. Journal of Knowledge Management, Vol 12 (2), 1367-80.

Kline, R.B. (2005). Principles and Practice of Structural Equation Modeling. 2nd ed., Guilford Press, New York, NY. 
Lim, K.K., Ahmed, P.K. and Zairi, M. (1999). Managing for quality through knowledge management. Total Quality Management, 10 Nos 4/5, 615-21.

Lin, C. and Kuo T.(2007). The mediate effect of learning and knowledge on organizational performance, Industrial Management $\mathcal{E}$ Data Systems, 107 (7), 2007, 1066-83.

Marquardt, M.J. (1996). Building the Learning Organization. McGraw-Hill, New York, NY.

Rezgui, Y. (2007). Knowledge systems and value creation: an action research investigation. Industrial Management $\mathcal{E}$ Data Systems, 107 (2), 166-82.

Ruggles, R. (1998). The state of the notion: knowledge management in practice. California Management Review, 40 (3), 80-9.

Sarvary, M. (1999). Knowledge management and competition in the consulting industry. California Management Review, 41 (2), 95-107.

Shih, H.A. and Chiang, Y.H. (2005). Strategy alignment between HRM, KM, and corporate development. Information Journal of Manpower, 26 (6), 582-603.

Singh, M.D., Kant, R. and Narain, R. (2008). Knowledge management practices: a sectorial analysis. International Journal of Innovation and Learning, 5 (6), 683-710.

Sviokla, J.J. (1996). Knowledge workers and radically new technology, Sloan Management Review, 37 (2), 25-40.

Tanriverdi, H. (2005). Information technology relatedness, knowledge management capability, and performance of multibusiness firms. MIS Quarterly, 29 (2), 311-34.

Tiwana, A. (2002). The Knowledge Management Toolkit: Orchestrating IT, Strategy, and Knowledge Platforms. Prentice-Hall, Englewood Cliffs, NJ.

Wall, T. D.,Michie, J., Patterson, M.,Wood, S. J., Sheehan, M., Cleeg, C. W., \& West, M. (2004). On the validity of subjective measures of company performance. Personnel Psychology, 57, 95-118.

Weber, E.S., Liou, Y.I., Chen, M. and Nunamaker, J.F. (1990). Toward more intelligent organizations. 23rd Hawaii International Conference on Systems Science, 4, 290-9.

Wiseman, C. (1988). Strategic Information Systems. Irwin, Homewood, IL.

Wright, P. and Boswell, W. (2002). Desegregating HRM: a review and synthesis of micro and macro human resource management research. Journal of Management, 28 (3), 247-76.

Wu, I., \& Chen, J. (2014). Knowledge Management Driven Firm Performance: The Roles of Business Process Capabilities and Organizational Learning. Journal of Knowledge Management, 18(6) , 1141-64.

Zack, M.H. (1999). Developing a knowledge strategy. California Management Review, 41 (3), $125-45$. 